All the same trees are present, but there is no marked predominance of the alder. The transition through the bed from an early dominance of oak to a dominance of alder suggests increasing wetness and an increasing prevalence of alder swamp. This is borne out by the pollen of herbaceous plants which are aquatic in character. At the bronze age occupation level Titia has a maximum of 15, an unusually high figure for post-glacial peats; but the occurrence of a similar high percentage elsewhere in the Fens suggests that Tilia may afford a valuable chronological index for the Fens as a whole. The Early Bronze Age settlement thus falls in the sub-Boreal period.

Combining the evidence from the reports on the Foraminifera by Dr. Macfadyen and on the freshwater Mollusca by Mr. A. S. Kennard, there would appear to have been certain changes in elevation in the history of the site. The point at which the Tardenoisian implement was found by boring in the lower peat now lies at $-22 \frac{1}{2} \mathrm{ft}$. O.D. Consequently at the date of that occupation the site must have been at a considerably higher elevation in relation to the sea than it is at present. A channel was at that time eroded through the peat and this was afterwards drowned by tidal estuarine silts of semi-marine character during a depression of the land in Atlantic times. A re-elevation took place, during which a channel, now $15 \mathrm{ft}$. below O.D., was eroded. This cuts into the marine silts and contains fresh-water Mollusca and the scales and bones of pike, pointing to a deep fresh-water river. The minor maximum of aquatic plants found to occur between two inches and nine inches from the base of the upper peat supplies a direct motive for the Early Bronze Age occupation in the shape of a dry 'island' situate in a shallow peat forming swamp. After a temporary recession, wet conditions set in again and ultimately caused the whole neighbourhood to be covered thickly with peat.

\title{
Annual Conference of the Association of Special Libraries and Information Bureaux
}

$\mathrm{T}$

HE tenth Annual Conference of the Association of Special Libraries and Information Bureaux was held at Wills Hall, Bristol, on September 22-25. The report presented to the annual meeting indicated that despite the admirable work the Association is doing, there have been decreases during the year both in membership and in income. The Council is arranging for an intensive new membership campaign and the decision to hold the meeting at Bristol was part of a definite attempt to break new ground.

One of the features of the programme was a symposium on the Saturday morning devoted to the preparation and production of information bulletins, house journals and reports. The first paper presented to this symposium, by Mr. J. C. Stopani Stuart, of Messrs. Armstrong Whitworth and Co. Ltd., gave a broad survey of the general methods of organising a research or information bureau, but with this exception the papers might be regarded as falling into two groups : those dealing with the collection of material and those concerned with its reproduction. The first group of papers contained contributions from representatives of the British Non-Ferrous Metals Research Association, the British Cast Iron Research Association, the Mond Nickel Co. Ltd. Messrs. Edgar Allen and Co. Ltd. and the Metropolitan-Vickers Electrical Co. Ltd., and the detail with which the methods employed for the collection, selection and circulation of material used in the various abstract publications or information bulletins of these various organisations were described made the discussion of the utmost value to those engaged in such work. It is beyond question that the Association of Special Libraries and Information Bureaux provides in its annual Conference an unrivalled opportunity for comparing technique and discussing both general and special problems in this field.

The second group of papers, represented by those of Mr. G. T. Clarkson, of the Royal Aircraft Establishment, on the preparation and reproduction of illustrations for technical reports and of Mr. Norman Parley on facsimile processes with special reference to tabular work, were concerned with a special aspect of the same problem on which information is not so freely accessible as might be desired. Together these two papers contain much highly technical information as well as comparisons of different methods of reproduction available for tables and for illustrations which should have a wide range of utility. The service would be the greater if the Association could follow up the papers by compiling and issuing standard figures for the comparative costs of reproduction by different processes, having regard to the number of copies, type of finish and degree of permanence required.

This symposium was followed by a discussion on abstracting methods with particular reference to efficiency and economy. The discussion arose from a paper by Prof. J. C. Philip in which he gave a succinct account of the recent policy of the Bureau of Chemical Abstracts and emphasised the importance of developing co-operation between the various bureaux concerned with abstracting if the available resources are to be adequate for the task. As an example, Prof. Philip referred to relations which are being developed with the Bureau of Animal Nutrition. Possibilities with regard to the utilisation of the same abstracts for different purposes by several bureaux or abstract journals are obvious to the independent observer, and the practical difficulties which exist are not sufficiently great to stand in the way of the advantages to be reaped by co-operation. Even within the fields of a single science such as chemistry, however, individual societies like the Society of Public Analysts persist in duplicating the work of the abstracting bureaux, apparently through the mistaken belief that an abstract should not be a pointer to the paper but provide in itself detail for experimental work. Only the really wealthy can afford to indulge in such a policy with any efficiency.

Apart from these discussions, the programme contained other specialist contributions such as that of Mr. S. W. Gibson on the classification of subject titles for engineering periodicals, in which he urged the advantage of some measure of control in the titles of papers in this field such as could be supplied by the use of an agreed guide. Mr. Evans Lewin indicated the need for co-ordination in bibliographical work within the British Empire, while Mr. B. M. Headicar described recent developments in equipment.

One of the most interesting sessions, however, was that at which Sir John Russell, under the title 
"Books and Farmers", gave a delightful exposition of the possibilities of educational work in the agricultural community by the county library and others, and stressed the importance of good literature on English rural life as well as of popular expositions of the more technical or scientific side of agriculture.

At the final session, over which the Master of Sempill presided, Major H. Hemming delighted a large audience with his lantern lecture on "Air Survey Work: Its Various Aspects and Uses", in which he not only gave illustrations of results already achieved but also indicated the value of this new method of survey in development work generally, particularly when used in conjunction with other surveying methods. Major Hemming's lucid but restrained exposition prompted a discussion as to the means by which the results of such survey work could be made available on a national scale, and led to the suggestion that the Association of Special Libraries and Information Bureaux should itself investigate the possibility of establishing a clearinghouse for this class of information.

\section{University and Educational Intelligence}

THE Hokkaido Imperial University of Japan announces in its calendar for 1933-34 that to the existing faculties of agriculture, medicine, technology and science will almost certainly be added in the near future a faculty of liberal arts. The calendar reproduces the imperial ordinances relating to the appointment of foreigners to professorial and other posts, but at present the only foreigners on the staff are five language instructors in the College preparatory school. There are 2,400 students on the roll of the University.

THE National Federation of Class Teachers held its thirty-ninth annual conference this year at Bristol. The delegates, to the number of two hundred, were accorded a civic welcome on September 29 by the Lord Mayor, the Vice-Chancellor of the University, and other representatives of phases of the life of the city. The subject of the presidential address, delivered by Miss A. M. Edwards, of Liverpool, was the advisability of raising the age limit of compulsory school attendance. In recapitulating the now familiar arguments in favour of this change, Miss Edwards touched on two crucial points : whether an additional year or more of compulsory schooling would result in (1) the schools turning out better recruits for industry and commerce, (2) promoting a taste and capacity for the right use of leisure. On the first point she protested against the "rash statements made at present by employers about the ineffectiveness of our present school system and what seems to them the failure of the schools to provide an education which will fit the child for industry," and directed attention to the lead given by governments in many other countries (the United States of America, Canada, South Africa, New Zealand, Norway, Switzerland and Hungary) where the school-leaving age has already been raised to fifteen years or higher, with the result, it is assumed, that England will be at a hopeless disadvantage in international competition unless she soon does likewise. Mention was made, with qualified approval, of a suggestion by Lord Eustace Percy that the raising of the age should be in stages, one term per year during 1935,1936 and 1937.

\section{Levanter}

\section{Calendar of Nature Topics}

A characteristic type of pressure distribution in winter and spring shows an anticyclone over central Europe and a barometric depression over the southwestern Mediterranean, while a strong squally northeast wind, known as the 'levanter', blows along the east coast of Spain. The levanter occurs most frequently in October-December and again in February-May, and often persists for two or three days. In the funnel-like western extremity of the Mediterranean the force of the wind is concentrated, and it blows through the Straits of Gibraltar as a very powerful east wind. The Rock of Gibraltar, standing in the path of this wind, causes remarkable eddies on its lee side. In summer the levanter is less frequent and is rarely strong.

\section{English Pheasants}

A hundred years ago, the English sportsman follow. ing pheasant shooting heralded the coming of October as a great event, though 'walking-up' was practically the only method followed, for his single-barrelled muzzle-loader limited his shots to too lengthy periods for much covert shooting. The first authentic records of the pheasant (Phasianus colchicus) in Britain seem to be in the eleventh century, though it was said to have been brought over by the Romans. As a result of game-keeping, the bird has increased to large numbers, and it has been estimated that since the Game Act of 1831, pheasants have been increased more than one thousand per cent in Great Britain. More than 3,000 pheasants have been shot in a day on certain estates, with the record for Great Britain believed to be 3,937 at Beaconsfield, Buckinghamshire (Hugh Gladstone). During recent years, the appearance of the melanistic-mutant sport, a very dark form, of the pheasant (Phasianus tenebrosus) created much interest. J. C. Hunting (Field, September 10 , 1932) describes two strains of the mutant, in one of which the chicks are black, black and white or dark brown with white patches, the adult cocks having very dark green plumage and the hens mottled dark brown and russet with an irregular barring of light buff; and the second with the chicks unevenly marked black and white with black predominating, and the adult cock mostly very dark metallic green and black, the hen being a mixture of brown and black, and many feathers of her head and breast edged with dark metallic green.

Asia Minor is the home of the common English pheasant, but it has long been encouraged and transported from its original habitat, possibly the Athenians being the first to do so. The first protection laws in England were in the reign of Henry VII, when it was made an offence to take a pheasant, and in the time of Henry VIII the privilege of buying and selling the birds was confined to the royal household, with a year's imprisonment as the penalty for stealing the eggs. An Act of James I provided, for the first time, a close season for the birds.

\section{Breeding of Great Grey Seals}

An Act of Parliament of 1914 protected all grey seals (Halichœrus grypus) in Great Britain between October 1 and November 15, because at that time the species brings forth its helpless young on bare islands and rocks, or in the caves of the roughest coasts, chiefly on the west coast of Scotland, Ireland 